\title{
Severe Undervirilisation in a 46,XY Case Due to a Novel Mutation in HSD17B3 Gene
}

\author{
Ayfer Alikaşifoğlu1', Doğuş Vurallı1, Olaf Hiort2, Nazlı Gönç1, Alev Özön1, Nurgün Kandemir1 \\ 1 Hacettepe University Faculty of Medicine, Department of Pediatrics, Division of Pediatric Endocrinology, Ankara, Turkey \\ 2 University of Lübeck Faculty of Medicine, Department of Pediatrics, Division of Pediatric Endocrinology and Diabetes, Lübeck, Germany
}

\begin{abstract}
$17-\beta$-hydroxysteroid dehydrogenase type 3 (17 $\beta$-HSD3) is an important enzyme involved in the final steps of androgen synthesis and is required for the development of normal male external genitalia. 46,XY individuals with deficiency of this enzyme present a wide clinical spectrum from a female appearance of the external genitalia through ambiguous genitalia to a predominantly male genitalia with micropenis or hypospadias. This paper reports a one-year-old 46,XY patient with 173-HSD3 deficiency who presented with female external genitalia and bilaterally palpable gonads in the inguinal region. The low $T / \Delta 4$ ratio after human chorionic gonadotropin (hCG) stimulation suggested 17/-HSD3 deficiency. A homozygous mutation, c.761_762delAG, was determined at the intron 9/exon 10 splice site of the HSD17B3 gene. To the best of our knowledge, this mutation has not been reported thus far, but its localization and type would imply a complete disruption of the 17ß-HSD3 which may explain the phenotype of our patient. Key words: 17 beta-hydroxysteroid dehydrogenase type 3, 46,XY disorders of sex development, delta-4-androstenedione
\end{abstract}

Conflict of interest: None declared

Received: 19.04 .2015

Accepted: 23.05 .2015

\section{Introduction}

17- $\beta$-hydroxysteroid dehydrogenase type 3 (17 $\beta$-HSD3) deficiency (OMIM \#264300), also previously described as 17-ketosteroid reductase deficiency, is a rare autosomal recessive form of a $46, \mathrm{XY}$ disorder of sex development (DSD) and is the most common testosterone biosynthesis defect (1). The $17 \beta$-HSD3 enzyme is found mainly in the testes and is involved in the conversion of $\Delta 4$-androstenedione, which is a weak androgen, to testosterone, which is biologically more active. The $17 \beta$-HSD3 enzyme family includes at least 14 isoenzymes identified thus far and these isoenzymes contribute to reproductive organ development by playing a role in the final steps of androgen and estrogen syntheses (2).

The actual incidence of $17 \beta$-HSD3 deficiency is unknown; however, previous studied have reported that the estimated incidence is 1/147 000 in newborns and that the calculated heterozygote frequency is 1/135 (3). However, higher incidence rates have been observed in places where consanguineous marriage is common, such as Middle Eastern countries (4).

$46, X X$ individuals with a deficiency of this enzyme are asymptomatic and difficult to diagnose since they have normal female genitalia and normal gender roles as well as uninhibited fertility $(4,5)$. On the other hand, 46,XY individuals may present a wide clinical spectrum from completely female appearing external genitalia (Sinnecker type 5) to slightly androgenized (Sinnecker type 4), frankly ambiguous genitalia (Sinnecker type 3 ) and to predominantly male genitalia with micropenis or hypospadias (Sinnecker type 2$)(3,6,7,8,9)$. Since the clinical findings of $17 \beta$-HSD3 deficiency are similar to other $46, \mathrm{XY}$ DSD forms, it may be difficult at times to establish the actual diagnosis and some of the $17 \beta-H S D 3$ deficiency patients may be inadvertently diagnosed with androgen resistance (androgen insensitivity syndrome) or 5 - $\alpha$-reductase 2 deficiency. $17 \beta$ - 
HSD3 deficiency is diagnosed via hormonal evaluation and the diagnosis is confirmed by molecular genetic testing.

Herein, we report the case of a child who presented with bilateral palpable gonads in the inguinal region during infancy and female appearing external genitalia. A 46,XY karyotype was found and, subsequently, the child was diagnosed with $17 \beta-H S D 3$ deficiency after detecting a lower $T / \Delta 4$ ratio in the stimulation test with human chorionic gonadotropin (hCG) and confirmed by molecular genetic analysis of the HSD17B3 gene. This report is presented since $17 \beta$-HSD3 deficiency is a rare form of $46, X Y$ DSD and the mutation identified in our case has not been reported so far.

\section{Case Report}

A one-year-old girl was referred with the complaint of swelling in the right inguinal area. There was consanguinity in the family and the parents were first cousins. Physical examination revealed bilateral palpable gonads in the inguinal region. She had a female appearing genital status. A slight clitoral enlargement to $1.5 \mathrm{~cm}$ was observed although the vaginal and urethral orifices were separate. On ultrasonography, no Mullerian structures could be seen and the gonads were in the inguinal canal. The karyotype was determined as 46,XY. A hCG stimulation test was performed and following injection of $1500 \mathrm{U} / \mathrm{m}^{2} \mathrm{hCG}$ for 3 days, serum androgen concentrations were measured (Table 1). The test results showed that there was impairment in testosterone biosynthesis. Testosterone/ dihydrotestosterone ratio was 3.6, i.e. normal value. Testosterone/androstenedione ratio was found to be 0.107 ( $\mathrm{N}>0.8$ ), suggesting $17 \beta$-HSD3 deficiency.

Genetic analysis was made in order to confirm the diagnosis and molecular analysis of the HSD17B3 gene showed a homozygous mutation c.761_762delAG corresponding to p.E254VfsX10 in the patient; both parents were heterozygous. This deleterious mutation has likely caused a $17 \beta$-HSD3 deficiency in our patient, although this is a new mutation that has not been identified before, to the best of our knowledge. The parents did not accept sex reassignment into male and bilateral gonadectomy was performed. The histopathology of the gonads were consistent with testis and spermatic cord and no malignancy was seen.

\begin{tabular}{|c|c|c|}
\hline Hormone levels & Pre-hCG & Post-hCG \\
\hline $\mathrm{T}(\mathrm{ng} / \mathrm{dL})$ & $<20$ & 29.9 \\
\hline DHT $(p g / m L)$ & 14.4 & 82.5 \\
\hline Androstenedione $(\Delta 4)(\mathrm{ng} / \mathrm{dL})$ & $<30$ & 278 \\
\hline T/DHT (N: <20) & & 3.6 \\
\hline $\mathrm{T} / \Delta 4(\mathrm{~N}:>0.8)$ & & 0.1 \\
\hline
\end{tabular}

\section{Discussion}

The most frequent presentation of $17 \beta$-HSD3 deficiency is a $46, X Y$ case with female appearing external genitalia, labial fusion and a blind-ending vagina, with or without clitoromegaly (3). Most cases are not diagnosed at birth since they have female appearing external genitalia and are raised as female and the diagnosis of such cases is delayed until adolescence $(9,10,11,12)$. In pubertal years, these individuals who have been raised as female and have not undergone gonadectomy are only diagnosed when they present with primary amenorrhea or virilization of various degrees such as increased body hair growth, thickened vocal cords, male type of body development and an enlarged clitoris. Sometimes, as is in the current case, individuals present with inguinal hernia and palpable testes in the inguinal canal or in the labiosacrotal folds and are diagnosed during childhood $(3,9,11)$. Less often, individuals with micropenis or hypospadias are considered to be male at birth and raised accordingly (4). The extent of virilizativon of the individuals varies by the partial residual activity of the $17 \beta$-HSD3 isoenzyme in the testes and the conversion of androstenedione to testosterone by other isoenzymes found in the extratesticular tissues, such as the $17 \beta-H S D 5$ isoenzyme $(9,11,13,14,15)$. Virilization occurs also in puberty because of increased $\Delta 4$-androstenedione due to gonadotropin surge and increased conversion of androstenedione to testosterone in the extratesticular tissues $(12,14)$. Patients may also suffer pubertal gynecomastia resulting from the conversion of androstenedione to estrogen through the activities of aromatase and other $17 \beta$-HSD isoenzymes (16). As in the current case, urethral and vaginal openings are separated in most of the patients with female external genitalia; however, only a short urogenital sinus has been reported in some individuals $(11,17,18)$.

The clinical findings of $17 \beta-$ HSD3 deficiency are similar to androgen resistance or $5 \alpha$ reductase 2 deficiency and it is clinically difficult to differentiate between these conditions. $17 \beta$-HSD3 deficiency is diagnosed via hormonal evaluation and the diagnosis should be confirmed by molecular genetic testing. Typical hormonal finding of $17 \beta-H S D 3$ deficiency include an increased $\Delta 4$ androstenedione and reduced testosterone concentration. Patients can be diagnosed via basal hormone levels in adulthood and in mini puberty during infancy (in infants aged below six months); however, the diagnosis may be missed unless hCG stimulation test is performed outside of these age periods. Our patient had a $\mathrm{T} / \Delta 4$ ratio $<0.8$ after hCG stimulation, which strongly suggests a $17 \beta-H S D 3$ deficiency. However, it should not be forgotten that this ratio may be low in other conditions related to testosterone synthesis such as dysgenetic testes $(11,19)$. Displaying the absence of Mullerian structures 
and the presence of Wolffian structures using imaging methods is helpful in the diagnosis but remains insufficient since these can be seen in $5 \alpha$ reductase 2 deficiency and androgen receptor mutations as well as $17 \beta-\mathrm{HSD} 3$ deficiency. Histological examination of the specimens from the gonad shows normal testicular structures and thereby, other causes involved in the etiology of $46, X Y$ DSD, such as testicular dysgenesis, are excluded.

The definitive diagnosis of $17 \beta-\mathrm{HSD} 3$ deficiency is established through genetic testing. The HSD17B3 gene is located on chromosome $9 q 22$ and homozygous or compound heterozygous mutations in this gene cause $17 \beta$-HSD3 deficiency (8). As far as we know, there are 29 mutations identified in this gene at this time. These mutations include intronic splice sites, exonic deletions, missense and non-sense mutations $(20,21)$. A great majority of these mutations have been identified in the Arab population living in the Gaza strip. The most common mutation identified in the Arab population is the p.Arg80GIn mutation, which is a point mutation in exon 3 , codon 80 and 1 The mutations previously identified in the Turkish population are c6551;G-A, p.Ala188Val and c.777-783del_GATAACC mutations $(3,22)$. Among these, c655-1;G-A is a splice junction mutation and disrupts splice acceptance site; p.Ala188Val is a missense mutation and inactivates the enzyme; and c.777-783del_GATAACC causes a 7 base pair deletion and frame shift and subsequently a truncated protein (23). The mutation identified in the current patient is a new mutation that has not been previously reported. In our case, a homozygous mutation c.761_762delAG corresponding to p.E254VfsX10 was identified in the HSD17B3 gene. A deletion of two nucleotides in exon 10 was found, which leads to a frame shift and subsequently to premature termination within the protein. Another important point of $17 \beta-H S D 3$ deficiency is the lack of a phenotype-genotype correlation; different phenotypes have been reported in different individuals with the same genotype within the same family. Although the same homozygous mutation is seen in different individuals of the same pedigree, different $\mathrm{T} / \Delta 4$ ratios have been reported after hCG stimulation (18).

Sex assignment is a difficult and important decision in individuals with $17 \beta-$ HSD3 deficiency, as is in other DSD cases. Transition to the male gender role is observed in a considerable amount (39-64\%) of the individuals who have been raised as female, have not undergone gonadectomy and have experienced virilization in puberty $(1,4,11,15,20,24,25)$. There are no reports of gender changes in cases raised as males (25). It has been observed that individuals who have been raised as females and have undergone gonadectomy during childhood are often satisfied with the female gender role and a very few of these individuals desire gender reassignment in the future $(1,3,23)$. There is no association between the severity of the enzymatic defect and the adult social gender role and some cases are believed to have gender change possibly with the effect of social and cultural influences (1).

Some authors suggest that sex assignment and corrective surgeries at younger ages is more favorable for the child and the family to gain the gender role behavior, whereas some authors argue that it would be more favorable if the surgery is performed only after the child reaches an age to give his/her own consent and after obtaining his/her full consent $(26,27)$. What is important here is that a delay is possible until the child reaches an age to disclose his/her choice and to assist the family and the doctors in making the right decision. The 2006 Chicago Consensus Meeting indicates that male gender assignment should be determined in individuals with $17 \beta$-HSD3 deficiency, but there is no spermatogenesis in individuals raised as male, even though early orchidopexy is performed and such individuals are infertile and have a risk of $28 \%$ for developing germ cell malignancy, so it should not be forgotten to closely monitor such individuals in this regard $(28,29)$. Sex assignment should be determined in consideration of the social and cultural expectations of the society in which the family lives and religious convictions. If the male gender is assigned to the severely undervirilized individuals, such as the patient presented in this report, genital reconstruction may be difficult (30). There are also some opinions suggesting that the response of external genitalia to testosterone should be evaluated via testosterone injection before sex assignment and it would be appropriate to raise such individuals as male if there is an adequate response (30).

The important matter for sex assignment is that each case must be evaluated individually. In the current case, the patient's parents indicated that they wanted to raise their child as female due to the completely female-appearing external genitalia and with the effect of the society's sociocultural structure; therefore, an early gonadectomy was performed. During the follow-up of the patient, the necessary sex hormone replacements will be initiated in puberty and proper corrective surgeries such as cliteroplasty, vaginal dilatation, or vaginal constructive surgery can be performed, depending on the patient's wishes.

In conclusion, $17 \beta$-HSD3 deficiency is an autosomal recessive form of $46, X Y$ DSD. The diagnosis is made by appropriate endocrinological evaluation and a low $T / \Delta 4$ ratio and confirmed by molecular genetic testing. 17 $\beta$-HSD3 deficiency must be considered in all females presenting with inguinal hernia during infancy or childhood or having mild cliteromegaly and in all adolescent females presenting with virilization. Early and accurate diagnosis is important for the management and sex assignment of these patients, as well as for genetic counseling. Long-term follow-up is required for patients in terms of genitoplasty outcomes, sexual function, fertility and testicular malignancy risk. 


\section{References}

1. Mendonca BB, Inacio M, Arnhold IJ, Costa EM, Bloise W, Martin RM, Denes FT, Silva FA, Andersson S, Lindqvist A, Wilson JD. Male pseudohermaphroditism due to 17 beta-hydroxysteroid dehydrogenase 3 deficiency. Diagnosis, psychological evaluation, and management. Medicine (Baltimore) 2000;79:299-309.

2. Moeller $\mathrm{G}$, Adamski J. Integrated view on 17beta-hydroxysteroid dehydrogenases. Mol Cell Endocrinol 2009;301:7-19. Epub 2008 Nov 5

3. Boehmer AL, Brinkmann AO, Sandkuijl LA, Halley DJ, Niermeijer MF, Andersson S, de Jong FH, Kayserili H, de Vroede MA, Otten BJ, Rouwé CW, Mendonça BB, Rodrigues $\mathrm{C}$, Bode $\mathrm{HH}$, de Ruiter PE, Delemarre-van de Waal HA, Drop SL. 17Beta-hydroxysteroid dehydrogenase-3 deficiency: diagnosis, phenotypic variability, population genetics, and worldwide distribution of ancient and de novo mutations. J Clin Endocrinol Metab 1999;84:4713-4721.

4. Rösler A, Silverstein S, Abeliovich D. A (R800) mutation in 17 beta-hydroxysteroid dehydrogenase type 3 gene among Arabs of Israel is associated with pseudohermaphroditism in males and normal asymptomatic females. J Clin Endocrinol Metab 1996:81:1827-1831.

5. Mendonca BB, Arnhold IJ, Bloise W, Andersson S, Russell DW, Wilson JD. 17Beta-hydroxysteroid dehydrogenase 3 deficiency in women. J Clin Endocrinol Metab 1999;84:802-804.

6. Ulloa-Aguirre A, Bassol S, Poo J, Mendez JP, Mutchinick O, Robles C, Perez-Palacios G. Endocrine and biochemical studies in a $46, X Y$ phenotypically male infant with 17 -ketosteroid reductase deficiency. J Clin Endocrinol Metab 1985;60:639-643.

7. Sinnecker GH, Hiort O, Dibbelt L, Albers N, Dörr HG, Hauss $H$, Heinrich $U$, Hemminghaus $M$, Hoepffner $W$, Holder M, Schnabel D, Kruse K. Phenotypic classification of male pseudohermaphroditism due to steroid 5 alpha-reductase 2 deficiency. Am J Med Genet 1996:63:223-230.

8. Geissler WM, Davis DL, Wu L, Bradshaw KD, Patel S, Mendonca BB, Elliston KO, Wilson JD, Russell DW, Andersson S. Male pseudohermaphroditism caused by mutations of testicular 17 beta-hydroxysteroid dehydrogenase 3. Nat Genet 1994;7:34-39.

9. Andersson $\mathrm{S}$, Geissler WM, Wu L, Davis DL, Grumbach MM, New MI, Schwarz HP, Blethen SL, Mendonca BB,Bloise W, Witchel SF, Cutler GB Jr, Griffin JE, Wilson JD, Russel DW. Molecular genetics and pathophysiology of 17 betahydroxysteroid dehydrogenase 3 deficiency. J Clin Endocrinol Metab 1996;81:130-136.

10. Rosler A. 17 beta-hydroxysteroid dehydrogenase 3 deficiency in the Mediterranean population. Pediatr Endocrinol Rev 2006;3(Suppl 3):455-461.

11. Lee YS, Kirk JM, Stanhope RG, Johnston DI, Harland S, Auchus RJ, Andersson S, Hughes IA. Phenotypic variability in 17betahydroxysteroid dehydrogenase-3 deficiency and diagnostic pitfalls. Clin Endocrinol (Oxf) 2007;67:20-28. Epub 2007 Apr 27

12. Andersson S, Russell DW, Wilson JD. 17beta-Hydroxysteroid dehydrogenase 3 deficiency. Trends Endocrinol Metab 1996;7:121-126.

13. Qiu W, Zhou M, Labrie F, Lin SX. Crystal structures of the multispecific 17beta-hydroxysteroid dehydrogenase type 5 : critical androgen regulation in human peripheral tissues. Mol Endocrinol 2004;18:1798-1807. Epub 2004 Apr 15

14. Eckstein B, Cohen S, Farkas A, Rosler A. The nature of the defect in familial male pseudohermaphroditism in Arabs of Gaza. $\mathrm{J}$ Clin Endocrinol Metab 1989;68:477-485.

15. Rösler A, Belanger A, Labrie F. Mechanisms of androgen production in male pseudohermaphroditism due to 17 betahydroxysteroid dehydrogenase deficiency. J Clin Endocrinol Metab 1992;75:773-778.
16. Castro-Magana M, Angulo M, Uy J. Male hypogonadism with gynecomastia caused by late-onset deficiency of testicular 17-ketosteroid reductase. N Engl J Med 1993;328:1297-1301.

17. Saez JM, Morera AM, De Peretti E, Bertrand J. Further in vivo studies in male pseudohermaphroditism with gynecomastia due to a testicular 17-ketosteroid reductase defect (compared to a case of testicular feminization). J Clin Endocrinol Metab 1972;34:598-600.

18. Bertelloni S, Maggio MC, Federico G, Baroncelli G, Hiort O. 17beta-hydroxysteroid dehydrogenase-3 deficiency: a rare endocrine cause of male-to-female sex reversal. Gynecol Endocrinol 2006;22:488-494.

19. Faisal Ahmed S, lqbal A, Hughes IA. The testosterone: androstenedione ratio in male undermasculinization. Clin Endocrinol (Oxf) 2000;53:697-702.

20. Mains LM, Vakili B, Lacassie $Y$, Andersson S, Lindqvist A, Rock JA. 17beta-hydroxysteroid dehydrogenase 3 deficiency in a male pseudohermaphrodite. Fertil Steril 2008;89:28. Epub 2007 May 16

21. Castro CC, Guaragna-Filho G, Calais FL, Coeli FB, Leal IR, Cavalcante-Junior EF, Monlleó IL, Pereira SR, Silva RB, Gabiatti JR, Marques-de-Faria AP, Maciel-Guerra AT, Mello MP, GuerraJunior G. Clinical and molecular spectrum of patients with 17beta-hydroxysteroid dehydrogenase type 3 (17-beta-HSD3) deficiency. Arq Bras Endocrinol Metabol 2012;56:533-539.

22. Alikasifoglu A, Hiort O, Gonc N, Demirbilek H, Isik E, Kandemir N. 17beta-hydroxysteroid dehydrogenase type 3 deficiency as a result of a homozygous 7 base pair deletion in 17betaHSD3 gene. J Pediatr Endocrinol Metab 2012;25:561-563.

23. George MM, New MI, Ten S, Sultan C, Bhangoo A. The clinical and molecular heterogeneity of 17betaHSD-3 enzyme deficiency. Horm Res Paediatr 2010;74:229-240. Epub 2010 Aug 3

24. Hiort O, Reinecke S, Thyen U, Jurgensen M, Holterhus PM, Schön D, Richter-Appelt H. Puberty in disorders of somatosexual differentiation. J Pediatr Endocrinol Metab 2003;16(Suppl 2):297306.

25. Cohen-Kettenis PT. Gender change in $46, X Y$ persons with 5alpha-reductase-2 deficiency and 17beta-hydroxysteroid dehydrogenase-3 deficiency. Arch Sex Behav 2005;34:399-410.

26. Money J, Hampson JG, Hampson JL. Hermaphroditism: recommendations concerning assignment of sex, change of sex and psychologic management. Bull Johns Hopkins Hosp 1955:97:284-300.

27. Kipnis K, Diamond M. Pediatric ethics and the surgical assignment of sex. J Clin Ethics 1998;9:398-410.

28. Houk CP, Hughes IA, Ahmed SF, Lee PA; Writing Committee for the International Intersex Consensus Conference Participants. Summary of consensus statement on intersex disorders and their management. International Intersex Consensus Conference. Pediatrics 2006;118:753-757.

29. Hughes IA, Houk C, Ahmed SF, Lee PA; Lawson Wilkins Pediatric Endocrine Society/European Society for Paediatric Endocrinology Consensus Group. Consensus statement on management of intersex disorders. J Pediatr Urol 2006;2:148162. Epub 2006 May 23

30. Farkas $A$, Rosler $A$. Ten years experience with masculinizing genitoplasty in male pseudohermaphroditism due to 17 beta-hydroxysteroid dehydrogenase deficiency. Eur J Pediatr 1993;152(Suppl 2):88-90. 